Annals of Warsaw University of Life Sciences - SGGW

Land Reclamation No 45 (1), 2013: 5-16

(Ann. Warsaw Univ. of Life Sci. - SGGW, Land Reclam. 45 (1), 2013)

\title{
Investigation of soil contamination level beneath the metallurgical waste landfill for the purpose of future reclamation works
}

\author{
EUGENIUSZ KODA ${ }^{1}$, TOMASZ KOŁANKA ${ }^{2}$, PIOTR OSIŃSKI ${ }^{1}$ \\ ${ }^{1}$ Department of Geotechnical Engineering, Warsaw University of Life Sciences - SGGW \\ ${ }^{2}$ GEOTEKO Geotechnical Consultants Ltd.
}

\begin{abstract}
Investigation of soil contamination level beneath the metallurgical waste landfill for the purpose of future reclamation works. One of the most important activities when preparing a land reclamation project of brow fields is a comprehensive analysis and documentation of subsoil conditions at the site. The article presents site investigation methodology conducted for the purpose of preparing land reclamation project of the metallurgical waste landfill, located in a close vicinity of a developed big city. The landfill was a part of the steel plant facilities where combustion by-products were disposed. The article presents range and methodology of contaminated soil survey, waste morphology and composition analyses as well as documentation of obtained results. The research consisted of both, site investigation and laboratory tests. A detailed analysis of the results allowed precise determination of soil contamination indicators, environmental impact zones and volumetric capacity of contaminated soil. On the bases of such methods, as geoelectrical tests, boreholes, geodetic surveys and laboratory chemical analyses of samples, several maps of contamination impact zones were prepared, which at the final stage allowed completing a complex brown field reclamation plan.
\end{abstract}

Key words: metallurgical wastes, soil contamination, remedial works

\section{INTRODUCTION}

The first stage of every land reclamation project is to comprehensively prepare a site investigation plan. It will determine the range, methods and techniques that could be applied when dealing with contamination (Chang et al. 2013). The paper is focused on specifying the zones and depths of the contaminated metallurgical waste landfill's subsoil, what was a part of a complete report describing the environmental conditions of the site. Due to a landfill closure decision issued by a legal body, such report was required to develop extensive brown field reclamation project. According to the landfill's legal motion as well as to the legal body's decision requirements, the scope of the landfill closure works cover: waste removal and transportation to the appropriate west management facility, removal of the landfill's technical infrastructure, site engineering and land reclamation. Furthermore, it is worth mentioning that the site is planning to be developed in the urban purposes. Thus to achieve the aim, the environmental and geophysical surveys, as well as complementary assessment of the waste material disposed at the site, were conducted. The scope of works allowing the comprehensive investigation should consists of (Koda 2011):

- analysis of the archive and the present landfill's monitoring results,

- analysis of the results presented in archive reports, 
- geodetic survey of the analysed area and verification of the landfill's dimensions,

- small dimension boreholes, with the soil and waste material sampling,

- geological and geophysical investigation to determine the depths of contaminated soil beneath the landfill,

- piezometers installation and the groundwater sampling,

- waste, soil and groundwater samples analytical laboratory tests,

- particle size distribution laboratory tests of the waste material and soil sampled from beneath the landfill,

- engineering specification.

As the range of engineering works is extensive, the present paper is limited to geological investigation analyses and results allowing determination of soil zones and levels of its contamination.

\section{MATERIAL AND METHODS}

\section{Testing site description}

The analysed landfill site is a part of the industrial facilities of the formal steel plant. The whole complex is situated within the distance of $10 \mathrm{~km}$ from the city centre. A development of the landfill environs is widely diversified. On the east and west part of the landfill some small-scale industrial and service providing enterprises are located. Within the closest surroundings of the landfill protecting green belt area is established. The green belt is $15-30 \mathrm{~m}$ wide. At the north-east part, not far away from the landfill protected landscape areas, NATURA 2000 and National Park are located. This overall view of the specific location of the landfill provides valuable informa- tion about the complexity of the environmental conditions present at the site.

The landfill was formed at the beginning of the 60's previous century. The material disposed on the landfill consisted of industrial waste products from steel plant and waste produced by enterprises related to the steel plant. The landfill was also used as a storage area for waste, such as metallurgical slag or non-combustible steel plant by-products, utilised for the further development.

A total area of the landfill is 34 ha, with the active zone (storage area) of 26 ha. The remaining space was developed as a technological park with offices and social facilities, with railway, technological roads, car parks, and with a protecting green belt. At the initial stage of the landfill exploitation all of the waste material from steel plant was disposed without any appropriate waste management plan, due to a specific character of waste. The later introduction of such a plan included: distinction of new storage zone boundaries, enhancement of the internal audit, and decrease of the steel plant waste material production.

The metallurgical waste landfill is geologically located within the upland. The first soil layer beneath the landfill consists of clayey sands (I packet). They occur as lenses of a thickness ranging from 0.1 to $5 \mathrm{~m}$, and their extension is limited. Beneath this layer, underlying water-bearing sands with clayey formation (packets I and II) are present. A considerable thickness of moderately permeable deposits (more than $100 \mathrm{~m}$ ), divides shallower (Quaternary) and deeper (Tertiary) aquifer layers and eliminates a danger of landfill's negative impact on the groundwater quality 
within the deeper horizons. The subsoil of the landfill and its environs consists of postglacial formations covering Tertiary deposits. They can be distinguished into five packets: sandy formations, clay formations, Tertiary Pliocene clays, sands and mudstones, Oligocene sands.

According the hydrogeological conditions the landfill is located within the zone, which first aquifer thickness exceeds $5 \mathrm{~m}$ ( $15 \mathrm{~m}$ max.). There are two main aquifer horizons: Quaternary and Tertiary. The shallower (Quaternary) aquifer mainly consists of sandy formations and is seriously exposed to contamination harm. There is a free water table flowing through this layer at the depth of 3-6 m, and the layer is being saturated mainly by water from participation.

Due to lack of significant composition changes (since 2004) of the waste disposed on the landfill, the assessment of waste morphology was based on the analysis of the information included in archival vague reports on the waste composition. The record of the waste produced and disposed on the landfill has been performed since 1976. The composition of the waste is presented in Table 1.

First attempts of reducing an environmental nuisance caused by inappropriate waste management on the landfill are dated on 70's and 80's previous century. They consisted of reducing the waste amount disposed on the landfill, by utilising it as a building material.

The landfill is a storage area of materials other than hazardous and neutral. Regarding the fact that none of the waste disposed on the landfill is biologically and chemically active, then the mixture of them also presents the same characteristics (Gworek et al. 2013). However, a lack of information about the composition of the waste disposed before 1976, disables such opinion to be accepted unconditionally. Some of the waste, regarding current requirements, could be recognised as hazardous. In this case, an evaluation of harmfulness of the waste should be based on the chemical analyses.

The detailed requirements concerning this issue are presented in regulation of Ministry of Economy and Labour (Dz.U. $2005 \mathrm{nr} 186$, poz. 1533). The analyses of the water extract samples collected from the landfill were tested in the laboratory of Voivodship Inspectorate for Environmental Protection (WIOŚ). All the values of the parameters analysed were lower than the acceptable ones, for the waste described as other than hazardous. It was assumed that the waste disposed did not include such amounts of hazardous substances that could classify them as hazardous. The laboratory results enabled determination whether the waste disposed on the landfill is other than hazardous. The test results determine the future waste management plan and reclamation works on the landfill (Koda 2012a).

The records of the waste disposed on the landfill or the waste recycled has not been kept recently, as there was lack of any activities, and the amount of the waste material on the landfill was constant. The inventory control consisted of determination of capacity of waste disposed on the landfill, and potential waste utilisation as a building material for earthworks.

In order to evaluate the amount of the waste actually disposed on the landfill, a geodetic survey of dumps and the reshaped landfill's body was conducted (Fig. 1). 
TABLE 1. Composition of waste disposed on the landfill in the past (Koda ed. 2012b)

\begin{tabular}{|c|c|}
\hline $\begin{array}{l}\text { Name of waste } \\
\text { material }\end{array}$ & Short characteristic of waste material \\
\hline \multicolumn{2}{|c|}{ Waste material usually disposed } \\
\hline $\begin{array}{l}\text { Metallurgical slag } \\
\text { (iron and steel slag) }\end{array}$ & $\begin{array}{l}\text { A typical steel plant by-product. Mainly steel slag, which properties depend } \\
\text { on furnace feed, time and type of steel melt in the furnace: slag from steel } \\
\text { air refining (black slag) and slag from fire refining (white slag). Martensitic } \\
\text { slag was also disposed, which properties are similar to black slag form elec- } \\
\text { trical furnaces but more bases. Almost harmless to environment }\end{array}$ \\
\hline $\begin{array}{l}\text { Debris from furnaces } \\
\text { demolition }\end{array}$ & $\begin{array}{l}\text { A waste material from the furnaces repair, consisting of ceramic furnaces } \\
\text { padding materials (heat resisting). Mainly high-alumina tremolite chamotte, } \\
\text { magnesite brick, chrome brick - could include chromium }\end{array}$ \\
\hline $\begin{array}{l}\text { Sludge and ash from } \\
\text { combustion gas treat- } \\
\text { ment }\end{array}$ & $\begin{array}{l}\text { The ash structure material, consisting of water insoluble elements, } \\
\text { including iron oxides, manganese, calcium, magnesium and silica. Some } \\
\text { amounts of zinc and lead can also appear. Elements like Cr, F pass into } \\
\text { a water extract, which is strictly base (pH 12) }\end{array}$ \\
\hline Founding waste & $\begin{array}{l}\text { The waste consists of moulding and core sand forming, during the process } \\
\text { of casting. Binder material used during production is water-glass (white } \\
\text { mass). A water extract consist of sodium salts, sodium silicate (high pH } \\
\text { value) }\end{array}$ \\
\hline $\begin{array}{l}\text { Sludge from gas } \\
\text { generators }\end{array}$ & $\begin{array}{l}\text { A solid by-product of gas treatment, which consist of fine silt particles of } \\
\text { coke coal of diameter }<5 \mathrm{~mm} \text { and high porosity. It also consists of slurry } \\
\text { tar, accumulated in clarifier during a treatment process and low-temperature } \\
\text { carbonised gas cooling. There is a significant amount of soluble organic } \\
\text { matter and elements such as ammonium, phenol, pyridine, and elements } \\
\text { susceptible to bromination - PAH and others. Harmful to groundwater }\end{array}$ \\
\hline $\begin{array}{l}\text { Post neutralisation } \\
\text { sludge }\end{array}$ & $\begin{array}{l}\text { The sludge generated during lime neutralisation of used pickling solutions. } \\
\text { Plastic mud consistency, consisting of hydrated calcium sulphate, iron } \\
\text { hydroxides, insoluble matter (silica, silicates), and little amounts of heavy } \\
\text { metals, which pass into solution after steel etching (Mn, } \mathrm{Cr} \text {, Ni and Ti). Ions } \\
\text { like } \mathrm{Ca}^{2+}, \mathrm{SO}_{4}^{2+} \text { and } \mathrm{Fe}^{2+/ 3+} \text { pass into water solution. The water extract } \\
\text { presents rather high pH value }\end{array}$ \\
\hline $\begin{array}{l}\text { Concrete and brick } \\
\text { rubble }\end{array}$ & $\begin{array}{l}\text { The waste material from repairs and demolition of steel plant buildings, } \\
\text { consisting of ceramic, concrete, and insulating materials }\end{array}$ \\
\hline \multicolumn{2}{|c|}{ Moreover, small amounts of other waste have also been periodically disposed } \\
\hline Post grinding waste & $\begin{array}{l}\text { A by-product of mechanical surface treatment of materials. It is a grinding- } \\
\text {-polishing dust, consisting of elements of iron and minerals insoluble in } \\
\text { water }\end{array}$ \\
\hline Used coolants & $\begin{array}{l}\text { An oil emulsion of various oil concentrations, contaminated mainly by } \\
\text { solid parts, including metals (Fe and other heavy metals) }\end{array}$ \\
\hline Cullet & $\begin{array}{l}\text { The waste from building workshop (mainly broken glass, glass packages, } \\
\text { panes) }\end{array}$ \\
\hline Melting loss and scale & $\begin{array}{l}\text { A by-product of rolling and forging, consisting of iron and elements similar } \\
\text { to these from metallurgical slag and some amount of scale from rolling } \\
\text { mill. The scale mainly consists of iron and solid mineral contaminants }\end{array}$ \\
\hline
\end{tabular}




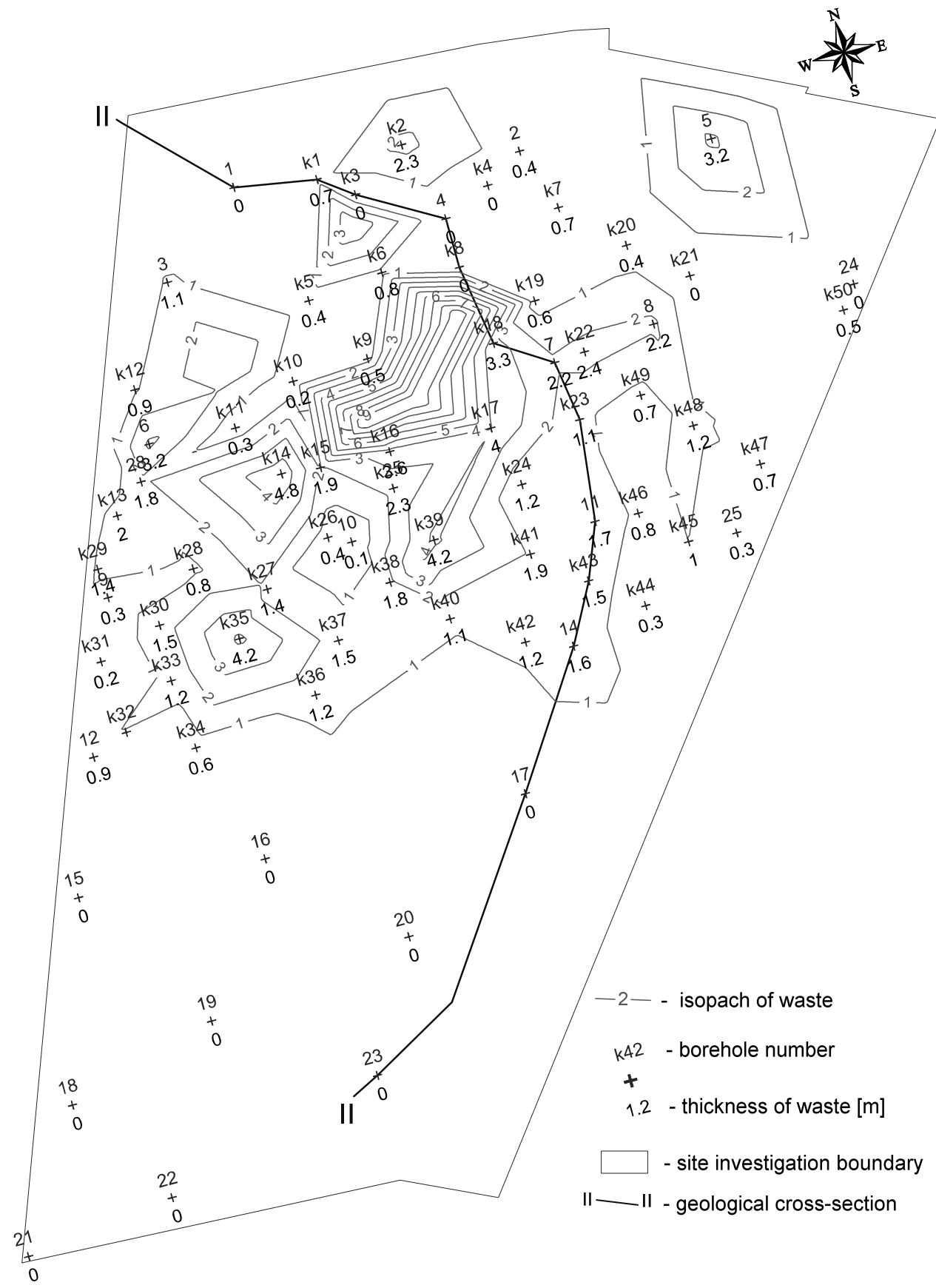

FIGURE 1. Sampling location map with geological cross-section and thickness of waste 
Additionally, due to the precise determination of the area of landfill's bottom, the penetration tests of the heap were conducted. The area of dumps was evaluated with use of geodetic methods (Guo-Li et al. 2013), and due to the huge differences in the landfill shape, some additional points were determined by the use of GPS equipment. During two measurement series, number of referring points was determined, what at the final stage provided numerically transformed total surface area, including the area of the waste dumps (Fig. 1). The bottom area was determined through the interpretation of penetration test and geoelectrical survey results (Namieśnik 1992; Hester and Harrison 1997; Koda 2012a). The maximum thickness of waste dumps reaches $10 \mathrm{~m}$ (Fig. 1). The cubic capacity of the waste actually disposed was evaluated as a difference between a surface and a bottom of the landfill and it equals $255,000 \mathrm{~m}^{3}$. Taking into account the average density of waste $\left(1.6-1.7 \mathrm{Mg} / \mathrm{m}^{3}\right)$, the total mass of waste body was evaluated to be $420,000 \mathrm{Mg}$. This value includes a mass of the aggregates formed during the slag treatment. Some amount of the aggregates was utilised as a building material for the landfill's access roads and car parks, allowing the proper performance of works.

\section{Methodology of soil investigation}

The aim of the investigation was to determine the boundaries of contaminated soil zones. The information obtained enables preparation of the reclamation and removal plan for the landfill area. The scope of works was divided into two stages (first stage accomplished in 2011 and second in 2012) and they consisted of:
- accomplishment of 80 boreholes of a depth of 5-11 m (total $316 \mathrm{~m}$ of drillings),

- soil sampling for laboratory tests,

- installation of 10 temporary piezometers for the groundwater sampling and hydrological survey purpose,

- geophysical survey with the use of the electrical resistivity method (3 cross-sections), in order to determine zones of the contaminated soil, - geodetic surveys, as the inventory control methods, and complementary evaluation of the waste dumps area, with the use of GPS methods.

The site investigation regarded additional penetration tests. They aimed at the waste material and soil investigation, required for the further analyses and precise determination of the landfill's bottom area. The results obtained became the input data for the evaluation of the actual cubic capacity of the waste present on the landfill. Within the scope of the investigation 50 small diameter boreholes were drilled to the depth ranging from 5 to $10 \mathrm{~m}$ (second stage of earthworks). Due to the drilling difficulties some borehole depths were limited (stiffness of soil). The total depth of drilling was 316 running meters. The location of boreholes drilled is presented on the map in Figure 1 and the examples of geological cross-section could be found in Figure 2. During the in situ tests also a macroscopic assessment of soil type and an organoleptic assessment of the soil contamination were conducted.

During the site investigation, an initial organoleptic assessment of the potential emission of volatile organic compounds was also undertaken (Wong et al. 1997). The sounding samples were 

collected from each $1 \mathrm{~m}$ (vadose zone) (and kept in foil bags) in order to determine the potential emission of VOC (volatile organic compound) with the use of photo-ionisation measurement method (PID) (Remona et al. 2005). The results obtained from PID measurement were also used in order to select the soil samples for the detailed chemical analysis. The soil sampling was undertaken also to determine a grain size distribution in the laboratory. From all the collected samples, 40 samples of soil were selected for the further detailed laboratory contaminants determination tests.

The analytical survey of soil contamination was aimed at the determination of contaminated zones boundaries, which would allow preparation of a complete landfill reclamation plan, after the landfill removal works are accomplished. The soil samples have been collected directly from auger, after removing a cover of the soil layer, to avoid a potential contamination caused during the sounding.

The next step was laboratory test of the soil contamination (Zadroga and Olańczuk-Neyman 2001; Ramachandra-Rao 2006). The range of the indicators determined within the tested soil samples included selected elements from the group specified in the regulation of Ministry of Environment (Dz.U. 2002 $\mathrm{nr} 165$, poz. 1359). The analyses were mainly aimed at the verification of the cubic capacity of soil requiring reclamation. Due to the urban development plan of the landfill's area, the results of soil quality were related to the standards of industrial areas (group C) as well as for the developed areas (group B) according to the regulation mentioned above.

\section{RESULTS AND DISCUSSION}

The PID detector tests proved that several organic concentration limits were exceeded by volatile substances (VOC $>$ $>10 \mathrm{ppm}$ ). Such surpass means that the soil samples collected from 17 boreholes (Fig. 3) could have been contaminated by the petroleum products. A high $(>100$ ppm) concentration of VOC was also observed in 5 other boreholes (Fig. 3, Table 2).

A significantly high emission of VOC (>500 ppm) was determined in the soil samples from borehole K13 (at depths of 1 and $2 \mathrm{~m}$ ), K17 (at depth of $2 \mathrm{~m}$ ). The analytical tests results obtained from the same boreholes revealed that soil in this point has been contaminated by petroleum products (gasoline and mineral oil). In most of the boreholes the samples, collected from depth of $0-3 \mathrm{~m}$ have been presenting slightly increased concentration of $\operatorname{VOC}(>10 \mathrm{ppm})$, which is the result of the particular type of the waste material disposed in the past.

Due to the current industrial exploitation of the landfill area, the obtained detailed laboratory tests results of values of contamination indicators were compared with the acceptable values of areas from group $\mathrm{C}$, according to the regulation of Minister of the Environment (Dz.U. 2002 nr 165, poz. 1359). Moreover, due to the fact that after the concerned area will be restored and will be used as an urban development area, the obtained tests results were also compared with acceptable values of areas from group B. 10 primary indicators (selected after analyses of results obtained for I stage of the survey) were determined from significant number of soil samples collected from the closest landfill's environs. 


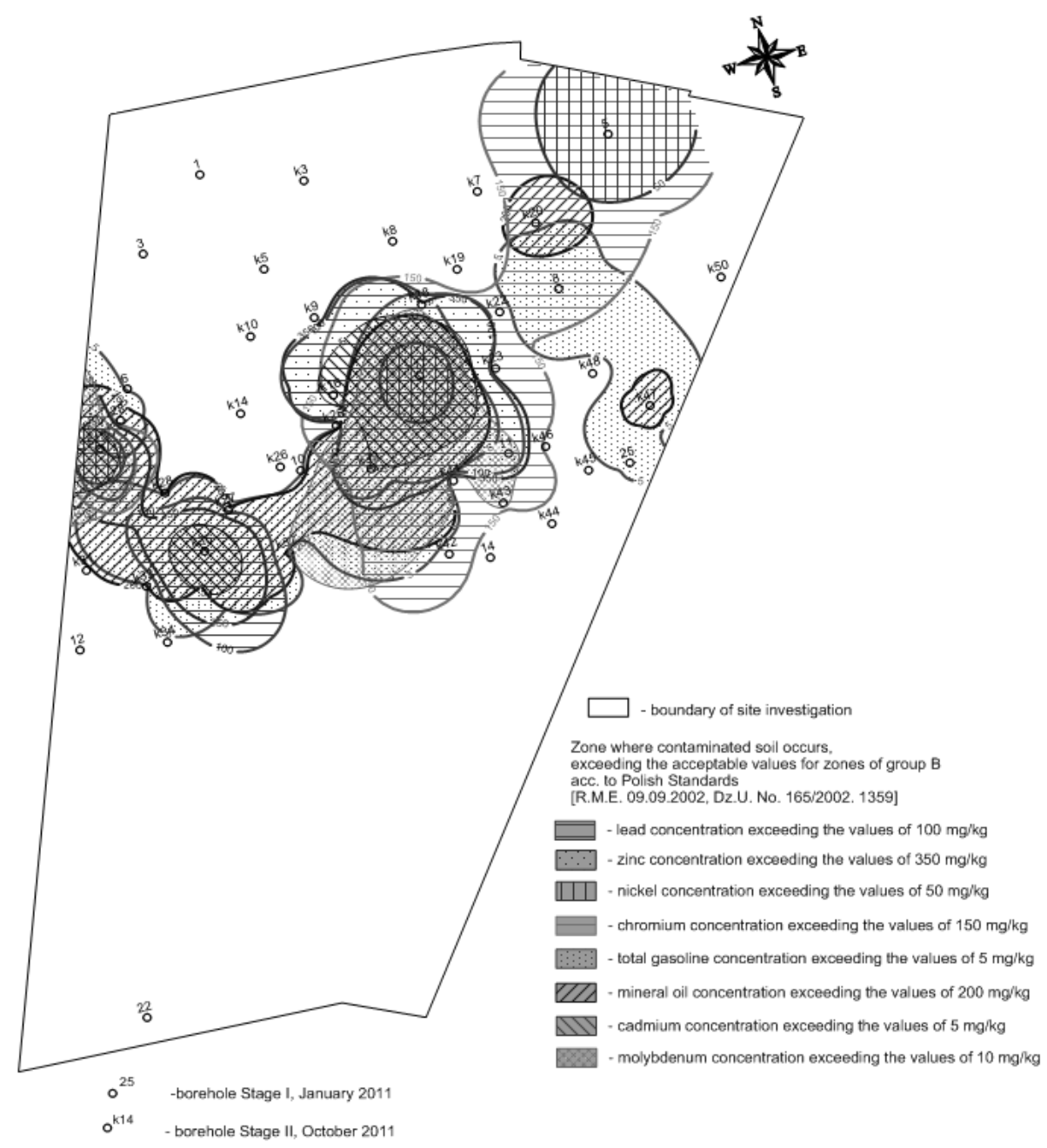

FIGURE 3. Distribution map of selected contamination indicators for metallurgical waste landfill

Due to the sampling location within the area of contaminated zone, for significant number of samples collected, the values of quality standards for areas from group $\mathrm{C}$ were exceeded (exceeded values of: chromium, zinc, cadmium, molybdenum, lead, gasoline and mineral oil). Further estimation proved that values of quality standards of areas from group B were also exceeded.
The results obtained from laboratory test were a base for precise determination of contaminated soil zones. The zones, for which standard quality values of the soil from group B were exceeded, have been mapped (Fig. 3). The extent of contaminated zones was interpolated on the basis of the tests results obtained from the survey. A significant part of the contaminated soil area encloses within one 
TABLE 2. Comparison of selected soil samples tests results with acceptable values of particular groups of soil types according to the regulation (Dz.U. $2002 \mathrm{nr}$ 165, poz 1359)

\begin{tabular}{|c|l|l|l|l|l|l|l|}
\hline \multirow{2}{*}{ No } & \multirow{2}{*}{$\begin{array}{l}\text { Contamination } \\
\text { indicators }\end{array}$} & \multicolumn{5}{|c|}{ Borehole number/Soil sampling depth [m] } \\
\cline { 3 - 8 } & & \multicolumn{5}{|c|}{ concentration of contaminants in soil [mg/kg dry mass] } \\
\cline { 3 - 8 } & & K 13/1.5 & K 13/2.5 & K 14/5.2 & K 16/3.8 & K 17/0.7 & K 17/4.5 \\
\hline 1 & Chromium & 771 & 157 & 77.9 & 169 & 652 & 172 \\
\hline 2 & Zinc & 1,920 & 217 & 34.9 & 2,030 & 5,940 & 609 \\
\hline 3 & Cadmium & 8.22 & 2.22 & $<0.25$ & 6.97 & 18.4 & 2.09 \\
\hline 4 & Cobalt & 10 & 19.2 & 4.84 & 5.86 & 13.4 & 4.39 \\
\hline 5 & Copper & 410 & 75.4 & 7.87 & 31.7 & 126 & 28.7 \\
\hline 6 & Molybdenum & 27.2 & 5.84 & $<1$ & 3.7 & 21.8 & 31.9 \\
\hline 7 & Nickel & 95.6 & 20.8 & 10.3 & 14.5 & 87.3 & 21.7 \\
\hline 8 & Lead & 305 & 44 & 5.84 & 405 & 1,380 & 197 \\
\hline 9 & Total Gasoline & 3.54 & $<0.87$ & $<0.87$ & $<0.87$ & 15.6 & 21.7 \\
\hline 10 & Mineral oil & 6,000 & 700 & $<10$ & 25 & 640 & 9,700 \\
\hline
\end{tabular}

$\square$ - group A standards met or exceeded

- group B standards excceded

- group C standards excceded

zone of 10.5 ha. The reclamation ex situ works such as: excavated soil treatment or its transportation to the appropriate hazardous waste disposal facility, should be executed there. The cubic capacity of the waste requiring reclamation (ex situ method) was estimated as $110,000 \mathrm{~m}^{3}$.

\section{CONCLUSIONS}

The material presented in the paper was aimed at the determination of the amount of waste disposed on the landfill, and at specifying contaminated soil zones boundaries, within the landfill's subsoil. The results obtained allowed prepare a landfill removal plan, and the scope of the required soil remedial works. For the assessment of the soil contamina- tion, 80 penetration soundings were accomplished in two stages. The primary indicators in the number of 10 were determined from a number of soil samples collected from the closest landfill's environs.

The research revealed that the values of quality standards for areas from group $\mathrm{C}$ were considerably exceeded (exceeded values of: chromium, zinc, cadmium, molybdenum, lead, gasoline and mineral oil). Further estimation proved that values of quality standards of areas also from group B were exceeded for number of samples as well (copper, lead, chromium and gasoline contamination could be also observed). The contamination of most of the area does not surpass the depth of 0.5-1 $\mathrm{m}$ beneath the landfill's bottom. Significant part of the contaminated soil 
area encloses within one zone of 10.5 ha. The reclamation ex situ works, such as excavated soil treatment or its transportation to the appropriate hazardous waste disposal facility, should be executed. The cubic capacity of the waste material requiring reclamation (ex situ method) was estimated as $110,000 \mathrm{~m}^{3}$, what gives $200,000 \mathrm{Mg}$ mass in total.

Conducting a comprehensively prepared plan of the site investigation and its proper executing gives a wide range of information that are crucial for brown fields reclamation. Heaving a cubic capacity of soil to be removed and spatial analyses of contaminated area allows precise determination of remedial works to be implemented in the future. This could be direct soil excavation, ex situ soil washing or commonly used phytoremediation and bio-engineering. There are still many industrial areas that need immediate restoration as the environmental impact could be very harmful. The content of the article gives a solution how to basically start this very complex process.

\section{REFERENCES}

CHANG L., JUN C., GUOFU J., XIAOFENG C., LI W., CHANGMING F. 2013: Soil heavy metal pollution assessment near the largest landfill of China. Soil and Sediment Contamination 22 (4), 390-403.

GWOREK B., HAJDUK A., KODA E., GROCHOWALSKI A., JESKE A. 2013: Influence of a municipal waste landfill on the spatial distribution of polychlorinated dibenzo-p-dioxins and dibenzofurans (PCDDs/Fs) in the natural environment. Chemosphere. doi.org/10.1016/j.chemos phere.2013.03.037 (in press).
GUO-LI Y., TIAN-HE S., PENG H., JUN L. 2013: Environmental geochemical mapping and multivariate geostatistical analysis of heavy metals in topsoils of a closed steel smelter: Capital Iron \& Steel Factory, Beijing, China. Journal of Geochemical Exploration 130, 15-21.

HESTER R.E., HARRISON R.M. 1997: Contaminated land and its reclamation. Thomas Telford, London.

KODA E. 2011: Stateczność i migracja zanieczyszczeń z rekultywowanych składowisk odpadów przy wykorzystaniu metody obserwacyjnej [Landfill stability under reclamation and pollutant transport using the observational method]. Wyd. SGGW, Warszawa [Engl. summ.].

KODA E. 2012: Influence of vertical barrier surrounding old sanitary landfill on eliminating transport of pollutants on the basis of numerical modelling and monitoring results. Polish Journal of Environmental Studies 21 (4), 929-935.

KODA E. 2012a: Anthropogenic waste products utilization for old landfills rehabilitation. Annals of Warsaw University of Life Sciences - SGGW, Land Reclamation 44 (1), 75-88.

KODA E. (ed.) 2012b: Environmental and geophysical survey, in order to determine the landfill's subsoil contaminated zones, required for the removal plan and reclamation of Huta Arcelormittal Warszawa landfill area. CDM, Warszawa, 60.

NAMIEŚNIK J. 1992: Metody instrumentalne $w$ kontroli zanieczyszczeń środowiska [Instrumental methods in environnmental pollution monitoring]. Wydawnictwo Politechniki Gdańskiej, Gdańsk [in Polish].

RAMACHANDRA-RAO R. 2006: Resource recovery and recycling from metallurgical wastes. Vol. 7, 1-557.

REMONA E., BOUCHARDONB J.L., CORNIERA B., GUYB B., LECLERCA J.C., FAUREA O. 2005: Soil characteristics, heavy metal availability and vegetation recovery at a former metallurgical landfill: Implications in risk assessment and site restoration. Environmental Pollution 137 (2), 316-323. 
Rozporządzenie Ministra Środowiska w sprawie jakości gleby oraz standardów jakości ziem. Dz.U. 2002 nr 165, poz. 1359 [in Polish].

Rozporządzenie Ministra Finansów i Polityki Pracy w sprawie kryteriów oraz procedur dopuszczania odpadów do składowania na składowisku odpadów danego typu. Dz.U. 2005 nr 186, poz. 1533 [in Polish].

WONG H.C., LIM C.H., NOLEN G.L. 1997: Design of remediation systems. Lewis Publishers, Washington.

ZADROGA B., OLAŃCZUK-NEYMAN K. 2001: Ochrona i rekultywacja podtoża gruntowego. Aspekty geotechniczno-budowlane [Protection and reclamation of subsoil. Geotechnical-construction aspects]. Wydawnictwo Politechniki Gdańskiej, Gdańsk [in Polish].

Streszczenie: Badania stanu zanieczyszczenia gruntów w podtożu składowiska odpadów pohutniczych do opracowania projektu rekultywacji. Jednym z zadań podczas przygotowania projektu rekultywacji terenów zdegradowanych jest szczegółowa analiza i dokumentacja warunków gruntowych rozpatrywanego obszaru. W niniejszym artykule przedstawiono szczegółowy zakres badań gruntu na potrzeby stworzenia projektu prac rekultywacyjnych terenów składowiska odpadów pohutniczych, zlokalizowanego na tere- nach dużego miasta. Analizowane składowisko jest integralną częścią zakładów huty, na którym składowane były odpady poprodukcyjne. W artykule przedstawiono zakres oraz metodykę przeprowadzonych badań skażenia gruntu, analizę morfologii i składu odpadów pohutniczych wraz $\mathrm{z}$ ich dokumentacją. Na badania te składały się zarówno badania terenowe i laboratoryjne. Szczegółowa analiza uzyskanych wyników pozwoliła na precyzyjne ustalanie indykatorów zanieczyszczeń, stref ich zasięgu oraz objętości skażonych gruntów na analizowanym terenie huty. Dzięki zastosowaniu takich metod badawczych, jak sondowania geoelektryczne, wiercenia geologiczne, pomiary geodezyjne oraz laboratoryjne analizy chemiczne, stworzone zostały m.in. mapy stref zanieczyszczeń wraz ze stężeniami, co w dalszym etapie umożliwiło sporządzenie obszernego projektu prac rekultywacyjnych na terenie przeznaczonym pod przyszłe inwestycje urbanistyczne.

Stowa kluczowe: odpady pohutnicze, zanieczyszczenie gruntu, prace rekultywacyjne

\section{MS. received 28 June 2013}

\section{Authors' address:}

Katedra Geoinżynierii

Wydział Budownictwa i Inżynierii Środowiska

SGGW

ul. Nowoursynowska 159, 02-776 Warszawa

Poland

e-mail: eugeniusz_koda@sggw.pl 